\title{
WATER QUALITY AND HAEMATOLOGICAL INDICES OF CLARIAS GARIEPINUS FROM OGUN RIVER (NIGERIA)
}

\author{
Olaniyi Alaba OLOPADE *, Iyabode Olusola TAIWO **, \\ Comfort Opeoluwa OLUWOLEAND *** and Justin Ayaegbunem AKANKALI ****
}

* University of Port Harcourt, Department of Fisheries, Rivers State, Olaniyi.olopade@uniport.edu.ng

** Federal University of Agriculture, Institute of Food Security, Environmental Resources and Agricultural Research, Ogun State, Nigeria, iomtai@yahoo.com

*** Olabisi Onabanjo University, Department Animal Production, Agowiye, Ogun State, Nigeria, comfort_opeoluwa@yahoo.com

**** University of Port Harcourt, Department of Fisheries, Rivers State, justin.akankali@uniport.edu.ng

DOI: 10.1515/trser-2015-0068

KEYWORDS: hematological indices, water quality, Clarias gariepinus, Ogun River.

\section{ABSTRACT}

This study was conducted to assess the effect of water quality of the Ogun River on the haematological indices of the African catfish Clarias gariepinus. Samples of water and Clarias gariepinus were collected from Ogun River (Station I, Opeji and Station II, Lafenwa) to determine and compare effects of possible differences in water quality on haematological parameters of Clarias gariepinus. The results demonstrate that higher index values were recorded at station II than Station I for almost all the physicochemical parameters and only sulphate values from Stations I and II were statistically significant $(\mathrm{P}<0.05)$.

RÉSUMÉ: La qualité de l'eau et les indices hématologiques pour Clarias gariepinus dans la rivière Ogun (Nigéria).

Le but de cette étude a été d'évaluer l'effet de la qualité de l'eau de la rivière d’Ogun sur les indicateurs hématologiques du poisson chat africain Clarias gariepinus. Des échantillons d'eau et des poissons de l'espèce $C$. gariepinus ont été collectés de la rivière d'Ogun (Station I, Opeji et Station II, Lafenwa) afin de mesurer de comparer les effets possibles des différences de la qualité de l'eau sur les paramètres hématologiques de $C$. gariepinus. Les résultats ont mis en évidence le fait que dans la station II ont été enregistrés des valeurs plus grandes que dans la station I pour presque tous les paramètres physiques et chimiques mais ils ont aussi montré le fait que seul l'indicateur sulfate a des valeurs statistiquement significatives $(\mathrm{P}<0,05)$. (Nigeria).

REZUMAT: Calitatea apei și indici hematologici la Clarias gariepinus din râul Ogun

Prezentul studiu a fost efectuat pentru a evalua calitatea apei în râul Ogun, cu privire la indicii hematologici ai somnului african, Clarias gariepinus. Au fost colectate eșantioane de apă și pești din specia Clarias gariepinus din râul Ogun (stația I, Opeji și Stația II, Lanfewa) pentru a se determina și compara efectele posibilelor diferențe ale calității apei asupra parametrilor hematologici Clarias gariepinus. Rezultatele au arătat că în staţia II s-au înregistrat valori mai mari decât în stația I, pentru aproape toți parametrii fizico-chimici și doar valorile pentru indicele sulfat din cele două stații au fost statistic semnificative $(\mathrm{P}<0,05)$. 


\section{INTRODUCTION}

Water is the most abundant of natural resources and is essential for the survival of living organisms. However, the availability of water in the appropriate quantity and quality remains a key challenge in most aquatic systems because of pollution. Pollution is caused by anthropogenic processes as a result of industrialization and urbanization because industries and cities have historically been located along freshwater ecosystem such as rivers.

Nigeria has several significant riverine systems: about two thirds of the country lies in the watershed of the Niger River, and other major river systems include the Benue River, Cross River, Anambra River, Imo River, Kwa Iboe River, Ogun River and Oshun River. The Ogun River is the largest water body in the south western part of Nigeria. This river serves as a source of livelihood for artisanal fishers and other economic activities for a number of communities. Due to a long history of use, the river has been subjected to environmental degradation.

Surface-water pollution is highly visible in the Ogun River and the major pollutants and damaging processes associated with the water body include erosion, siltation, domestic and industrial wastes, effluent from abattoir, motor garages, mechanical shops, excreta disposal, agricultural activities and bathing washing. These pollutants have reduced the river water quality and quantity particularly where the human activities are well pronounced and have also become threats to aquatic life in the river. This is because aquatic organisms, including fish, accumulate pollutants directly from contaminated water and indirectly via the food chain (Mohammed, 2009) and the pollutants enter the blood stream through the process of absorption where their potential harmful effects are distributed throughout the body.

Blood forms about 2-3\% of the weight of fish. The blood composition of fish reflects its metabolic and physiological process and certain physiological dysfunctions in the body are reflected as alterations in blood. Blood parameters are important indicators of health status in animals and have been an indispensable tool in the diagnosis. The purpose of investigating blood composition of fish is to distinguish normal state from states of stress and health status.

This study was designed to investigate the water quality of Ogun River through analysis of some selected water quality parameters and examined haematological parameters of Clarias gariepinus caught from the study area.

\section{MATERIAL AND METHODS}

River Ogun is in the largest perennial river in South-Western part of Nigeria and it covers an area of $22.4 \mathrm{~km}^{2}$. The river rises in Oyo State near Shaki at $8^{\circ} 41^{\prime} 0^{\prime \prime} \mathrm{N} \mathrm{3} 3^{\circ} 28^{\prime} 0^{\prime \prime}$ E/ $8.68333^{\circ} \mathrm{N} 3.46667^{\circ} \mathrm{E}$ and flows through Ogun State into Lagos State (Ayoade et al., 2004).

Water sampling. The two stations (Opeji and Lafenwa) from Ogun River were chosen with consideration of the human activities in each area. Station I (Opeji) was thought to be less affected by pollution because of fewer human activities. Station II (Lafenwa) was thought to be highly polluted because of more intensive human uses in this section of the river. Samples were collected following the standard sampling guidelines and methods (WHO, 2004). The samples were taken into pre-sterilized bottles kept in ice-boxes and transported immediately to the laboratory for physicochemical analyses. Temperature, conductivity and $\mathrm{pH}$ were measured in situ using a temperature probe, conductivity meter and portable $\mathrm{pH}$ meter (model Hann HI 99300.HI 99301). Dissolved oxygen, hardness, nitrate, phosphate, sulphate, alkalinity and biological oxygen demand (BOD) were determined five days after sampling; samples were kept in a BOD bottle in a cool cupboard. The concentrations of sulphate and nitrate were determined in the laboratory using a Standard Colorimeter. 
Collection and preservation of fish blood. Fish samples of Clarias gariepinus ranging in weight from 450-1,050 g with lengths between 42 to $54 \mathrm{~cm}$ were collected from the same spots where water samples were collected between $09.00-10.00 \mathrm{~h}$ in the morning, with the aid of fishermen using gill nets. The fish were carried to the laboratory in large plastic containers full of natural water to avoid stresses and injuries as far as possible.

Blood collection. Live fish were put on a table in the laboratory. A damp cloth was used to cover the fish's head. A small sample of whole blood was drawn from the caudal vein into a tube containing dipotassium EDTA following the process described by Hrubec et al. (2000). The haematological parameters were determined by using the standard techniques as described by Jain (1986).

Total Red Blood Cell (RBC) and White Blood Cell (WBC) counts were determined. The Packed Cell Volume (PCV) was determined by microhaematocrit method, Haemoglobin (Hb) values were estimated by the alkali haematin method by Schalm (1965). Values of RBC were determined by the microscopic method in a counting chamber after dilution with Hayens solution. Estimation of WBC was done in the improved Neubauer haemocytometer chamber using $2 \%$ acetic acid as diluent. Total leucocytes counts were carried out with a Haemocytometer method. Mean Corpuscular Value (MCV), Mean Corpuscular Haemoglobin $(\mathrm{MCH})$ and Mean Corpuscular Hemoglobin Concentration (MCHC) were calculated values of PCV, Hb and RBC as described by Mitruka and Rawnsley (1977).

Analysis of data. Descriptive statistics was used to analyze the data collected, while means were separated using mean value and t-test at 5\% confidence level.

\section{RESULTS AND DISCUSSION}

Physico-chemical characteristics

The results of the physico-chemical parameters and the descriptive statistics of the samples collected at the two locations are presented in table 1 . Higher values were recorded at Station II than Station I for almost all physico-chemical parameters.

The $\mathrm{pH}$ values at Station I ranged from 7.05-8.81 with a mean value of $7.75 \pm 0.48$ while the $\mathrm{pH}$ value at Station II ranged from 7.31-8.45 with a mean value of $8.25 \pm 0.48$ which indicates that the river is slightly alkaline. The temperature ranged from $22-29.1^{\circ} \mathrm{C}$ with mean value of $26.00 \pm 1.47$ at Station I and the value ranged from $25-30^{\circ} \mathrm{C}$ at Station II with a mean value of $27.75 \pm 1.25^{\circ} \mathrm{C}$.

In the present study the observed dissolved oxygen ranged from $1.33-4.93 \mathrm{mg} / \mathrm{l}$ with mean value of $1.33 \pm 4.9$ at Station I and the value ranged from $1.22-4.40 \mathrm{mg} / \mathrm{l}$ with mean value of $2.75 \pm 0.75$ at Station II. BOD value of Ogun River water ranged from 1.20-1.47 mg/l at the station I and the values varied between $0.4-2.80 \mathrm{mg} / \mathrm{l}$ at Station II.

The mean value of the total dissolved solids (TDS) at Station I ranged from 46-108 ppm with a mean value of $73.50 \pm 13.58$ while that of Station II varied between 54 and 156 ppm with a mean value of $87.0 \pm 23.87$ and alkalinity at Station I ranged from $12-28 \mathrm{mg} / \mathrm{l}$ with a mean value of $20.00 \pm 3.27$ while that of Station II ranged from 16-38 mg/l with a mean value of $27.50 \pm 5.12$ respectively.

The total hardness concentration obtained in this study ranged from $72-118 \mathrm{mg} / \mathrm{l}$ with a mean value of $99.50 \pm 9.88$ and the value at Station II ranged from 16-38 mg/l with a mean value of $114.50 \pm 13.00$. The mean values of the conductivity at Station I varied between 92.00-281 us/cm with a mean value of $148.00 \pm 27.54$ while that of Station II ranged from $106-313 \mathrm{us} / \mathrm{cm}$ with a mean value of $172.25 \pm 48.68$. 
The mean values of nitrate ranged from $0.00-12.52 \mathrm{mg} / \mathrm{l}$ with a mean value of $3.25 \pm$ 3.25. At Station II, the values ranged from $0.03-27.94 \mathrm{mg} / \mathrm{l}$ with a mean value of $7.00 \pm 7.00$. Phosphate values ranged from $0.05-0.52 \mathrm{mg} / \mathrm{l}$ with a mean value of $0.25 \pm 0.25$ at Station I while that of Station II ranged from $0.77-0.24 \mathrm{mg} / \mathrm{l}$ with a mean value of $0.75 \pm 0.25$.

The sulphate values are $2.74-14.84 \mathrm{mg} / \mathrm{l}$ at Station I with a mean value of $7.75 \pm 2.56$ while that of Station II ranged from 10.00-39.84 mg/l with a mean value of $25.50 \pm 6.19$.

According to the results of physico-chemical characteristics of Ogun River, only sulphate values from Stations I and II were statistically significant $(\mathrm{P}<0.05)$, indicating a significant difference in sulphate values between the two sampling locations.

Table 1: Range values of physicochemical parameters at Opeji and Lafenwa; ${ }^{a}$ are significant at $\mathrm{p}<0.05$.

\begin{tabular}{|l|c|c|c|c|}
\hline Parameters & Range & Station I mean & Range & Station II mean \\
\hline Temperature $\left({ }^{\circ} \mathrm{C}\right)$ & $22.0-29.1$ & $26.00 \pm 1.47$ & $25.0-30.6$ & $27.75 \pm 1.25$ \\
\hline Conductivity $(\mu \mathrm{cm})$ & $92.0-218$ & $148.00 \pm 27.54$ & $106-313$ & $172.25 \pm 48.68$ \\
\hline DO $(\mathrm{mg} / \mathrm{l})$ & $1.33-4.93$ & $1.33 \pm 4.93$ & $1.22-4.40$ & $2.75 \pm 0.75$ \\
\hline $\mathrm{pH}$ & $7.05-8.81$ & $8.25 \pm 0.48$ & $7.31-8.45$ & $7.75 \pm 0.48$ \\
\hline Phosphate $(\mathrm{mg} / \mathrm{l})$ & $0.05-0.52$ & $0.25 \pm 0.25$ & $0.77-0.24$ & $0.75 \pm 0.25$ \\
\hline Nitrate $(\mathrm{mg} / \mathrm{l})$ & $0.00-12.52$ & $3.25 \pm 3.25$ & $0.03-27.94$ & $7.00 \pm 7.00$ \\
\hline TDS $(\mathrm{mg} / \mathrm{l})$ & $46-108$ & $73.50 \pm 13.58$ & $54-156$ & $87.00 \pm 23.87$ \\
\hline Sulphate $(\mathrm{mg} / \mathrm{l})$ & $2.74-14.84$ & $7.75 \pm 2.56^{\mathrm{b}}$ & $10.00-39.84$ & $25.50 \pm 6.19^{\mathrm{a}}$ \\
\hline BOD $(\mathrm{mg} / \mathrm{l})$ & $1.20-1.47$ & $0.00 \pm 0.41$ & $0.4-2.80$ & $1.25 \pm 0.63$ \\
\hline Hardness $(\mathrm{mg} / \mathrm{l})$ & $72-118$ & $99.50 \pm 9.88$ & $92-152$ & $114.50 \pm 13.00$ \\
\hline Alkalinity $(\mathrm{mg} / \mathrm{l})$ & $12-28$ & $20.00 \pm 3.27$ & $16-38$ & $27.50 \pm 5.12$ \\
\hline
\end{tabular}

The results of the mean values of the physicochemical parameters of the water samples from the two sampling points on the river segment are presented in table 1 while figure 1 shows the variations in $\mathrm{pH}$, temperature and alkalinity values. The table showed that there were significant $(\mathrm{P}<0.05)$ differences in the mean values of all the physicochemical parameters across the months.

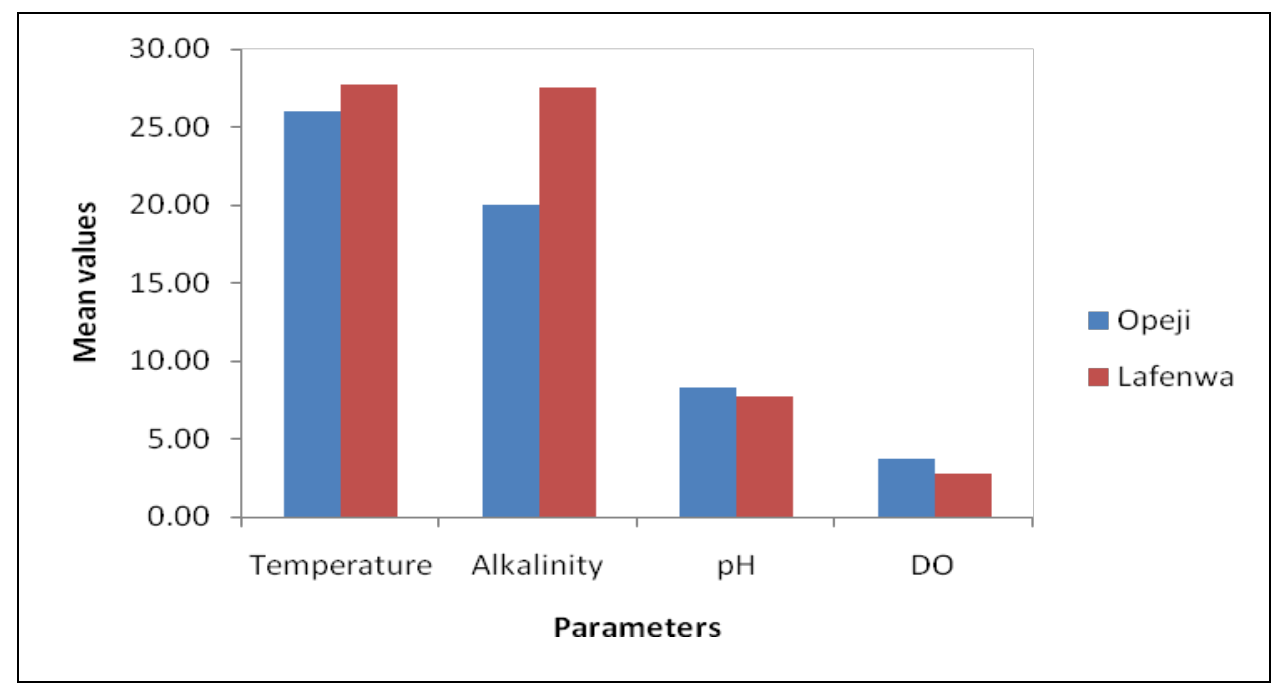

Figure 1: Water quality parameters in the two stations. 


\section{Haematological Indices of Clarias gariepinus from Ogun River}

The haematological indices results shown in table 2, revealed the mean values of PCV, $\mathrm{Hb}, \mathrm{Rbc}$, Het and MCHC in Station I were higher than Station II while the mean values of Wbc, MCH were higher in Station I than Station II. The haematological parameters were not significantly $(\mathrm{P}>0.05)$ different in the two stations.

Table 2: Haematological Indices of Clarias gariepinus from Ogun River.

\begin{tabular}{|l|c|c|}
\hline \multicolumn{1}{|c|}{ Parameters } & Station I & Station II \\
\hline PCV (\%) & $34.00 \pm 1.00$ & $31.00 \pm 2.00$ \\
\hline Hb (g/dl) & $11.30 \pm 1.10$ & $10.00 \pm 1.00$ \\
\hline RBC (x1012/L) & $3.10 \pm 0.30$ & $2.60 \pm 0.30$ \\
\hline WBC (x1012/L) & $15.00 \pm 1.50$ & $21.00 \pm 1.00$ \\
\hline Het (\%) & $37.00 \pm 1.00$ & $34.00 \pm 2.00$ \\
\hline Lym (\%) & $62.00 \pm 2.00$ & $66.00 \pm 1.00$ \\
\hline MCV (Fl) & $110.40 \pm 7.46$ & $119.94 \pm 6.15$ \\
\hline MCH (Pg) & $36.45 \pm 0.02$ & $38.53 \pm 0.60$ \\
\hline MCHC (g/dl) & $33.17 \pm 2.26$ & $32.18 \pm 1.15$ \\
\hline
\end{tabular}

Temperature influences the life of all biological organisms. During the period of study temperature recorded ranged from $26.00 \pm 1.47$ to $27.75 \pm 1.25^{\circ} \mathrm{C}$. Okayi et al. (2013) reported a lower surface water temperature $\left(20.00-23.10^{\circ} \mathrm{C}\right)$ in river Benue which contrasts with the result of this study, indicating that river Ogue has a higher average temperature. The mean $\mathrm{pH}$ values in the two locations ranged from $7.75 \pm 0.48-8.25 \pm 0.48$. The mean $\mathrm{pH}$ value obtained during this study falls within the EU acceptable limit for $\mathrm{pH}$ of six-nine for fisheries and aquatic life (Chapman, 1996).

Dissolved oxygen is crucial for aquatic organisms (Yakub and Ugwumba, 2009). Dissolved oxygen concentrations below five mg/l may adversely affect the functioning and survival of biological communities and below two mg/l may lead to the death of most fish. In the present study the observed dissolved oxygen mean values ranged from $2.75 \pm 0.75$ to 3.75 $\pm 0.95 \mathrm{mg} / \mathrm{l}$. The low dissolved oxygen in the study area could be attributed to a high degree of pollution by waste discharges high in organic matter and nutrients particularly in Station II. Is there any indication of this pollution from the physico-chemical parameters? If so then bring it in here - e.g. the DO levels are low around Station II, reflecting the higher incidence of chemical pollutants such as Nitrogen and K (potassium) - or whatever the results indicate.

Biological oxygen demand (BOD) is an important parameter which is widely used to determine the pollution load of waste water. WHO recommends a general standard of one $\mathrm{mg} / \mathrm{l}$. The mean BOD values of Ogun River water ranged $0.01 \pm 0.41$ (Station I) to $1.25 \pm 0.63$ $\mathrm{mg} / \mathrm{l}$ (Station II). The high value of BOD recorded at Station II was due to a higher rate of decomposition of organic matter at higher temperature, turbidity and in areas of lower water flow (Sanap et al., 2006).

The mean values of conductivity at Station I was $148.00 \pm 27.54 \mu \mathrm{cm}$ and at Station II was $172.25 \pm 48.68 \mu \mathrm{cm}$. The average value of typical, unpolluted river is approximately 350 $\mu \mathrm{cm}$ (Koning and Ross, 1999). Therefore the parameter does not give cause for concern in Ogun River. 
In the present study, the values of alkalinity ranged from $12-28 \mathrm{mg} / \mathrm{l}$ (Station I) to $16-38 \mathrm{mg} / \mathrm{l}$ which is below the permissible range. The range of alkalinity is $0.00-20.0 \mathrm{mg} / \mathrm{l}$ for low production, 20-40 mg/l for medium production and 40-90 mg/l for high production (Pandey and Shukla, 2005). However, the higher values recorded at Station II could be attributed to the quantity of waste in this section of the river. Nitrates are the final product of aerobic decomposition of organic nitrogenous compounds. The mean concentration of nitrate ranges from $3.25 \pm 3.25$ to $7.00 \pm 7.00 \mathrm{mg} / \mathrm{l}$. Nitrate levels exceeded optimum considering the global average of $0.1 \mathrm{mgl}-1$ in freshwater (Meybeck and Helmer, 1989). According to WHO (1994) levels in excess of $0.2 \mathrm{mg} / \mathrm{l}$ nitrate indicate eutrophic conditions in freshwater. The high mean nitrate values in this study may be due to the human activities which affect the river.

Swingle (1967) has suggested that a total hardness of $50 \mathrm{ppm} \mathrm{CaCO}_{3}$ equivalent to be dividing line between hard and soft water. Hard water contains large concentrations of alkaline earths dissolved from the drainage of calcium deposits (Wetzel, 1975). The increase in hardness can be attributed to the decrease in water volume and increase in the rate of evaporation at high temperature, high loads of inorganic substances, detergent, chlorides and other pollutants (Rajgopal et al., 2010) particularly at Station II.

During this investigation the mean TDS values ranged from 46-108 to 54-156 mg/l. This falls within the recommended value of $1,000.00 \mathrm{mg} / \mathrm{l}$ (WHO, 2004). TDS are comprised of inorganic salts (principally calcium, magnesium, potassium, sodium, bicarbonates, chlorides and sulphates) and small amount of organic matter that are dissolved in water.

Sulphate is found in almost all natural water, the values of sulphate recorded in station I (2.74-14.87 mg/l) were significantly lower than Station II (10.00-39.84 mg/l). Water sources with less than $10 \mathrm{mg} / \mathrm{l}$ indicate that the water sources is fresh and unpolluted (DWAF, 2001). High levels of sulphate in the study area particularly at Station II are indicative of some form of pollution.

In most natural waters, phosphorus usually ranges from 0.005-0.020 mg/l (Shinde et al., 2011). The phosphorus recorded in Station I (0.05-0.52 mg/l) and Station II (0.07-0.24 mg/l) was higher. According to Klein (1962) excess concentration of phosphorus of $0.015 \mathrm{mg} / \mathrm{l}$ and nitrogen concentration of about $0.3 \mathrm{mg} / \mathrm{l}$ are sufficient to cause algal bloom.

Haematological indices (RBC counts, concentration of haemoglobin and haematocrit) have been reported to indicate secondary responses of an organism to pollutants (O'Neal and Weirich, 2001). The mean values of PCV, Hb, Rbc, Het and MCHC in Station I were higher than Station II even though there were no significant changes in the haematological parameters of $C$. gariepinus in the two locations. A decrease in the concentration of haemoglobin in the blood, which is usually caused by the effect of toxic metals on blood, as well as decreases in oxygen also indicates anaemia or confirms negative changes occurring in fish (Ali et al., 2008). Decreases in RBC count, haematocrit and haemoglobin contents have also been reported by several workers after insecticide feeding (Mandal et al., 1986; Ali, 1989; Hamilton et al., 1978). These clearly indicate that the water pollution affects the haematological components of fish.

The higher values of WBC, Lym, MCH and MCV in Station II may be attributed to the higher level of pollutants in the station. Increase in MCV and normal MCH and MCHC were indication of Macrocytic-normochromic anaemia (Abubakar, 2013). 


\section{CONCLUSIONS}

Aquatic pollution undoubtedly has direct effects on fish health and survival. It can be concluded from the study that the river Ogun is polluted especially at the Lafenwa area of the river thus affecting water quality and haematological parameters. The study revealed that parameters like conductivity, TDS, DO, temperature, hardness, nitrate, sulphate and phosphate had higher values beyond standard values which indicate a polluted environment particularly in Station II. Parameters like MCHC, MCV and MCH in Station II were higher than in Station I, reflecting the greater presence of potential pollution sources at Station II. The increase and decrease of various haematological and blood biochemical parameters in test fish samples explains the ailment caused by the ambient pollutants. Therefore, there is need to regulate human activities in and around the river for the benefit of diverse fish species and the livelihood of the local fishers.

\section{ACKNOWLEDGEMENTS}

The authors would thank to Curtean-Bănăduc A. and Bănăduc D. for their continuous editorial support.

\section{REFERENCES}

1. Abubakar M. I., 2013 - Toxicity of 2, 3-dichlorovinyl dimethyl phosphate Sniper (1000EC) on Clarias gariepinus (Burchell, 1822) and Oreochromis niloticus (Trewavas, 1983) under laboratory conditions, PhD Thesis, Department of Aquaculture and Fisheries Management, Federal University of Agriculture, Abeokuta, Nigeria, 184.

2. Ali M. Y., Abdur R. K. and Shakoori A. R., 2008 - Hematological and biochemical responses of blood of an endangered South Asian fresh water fish, Tor putitora against aquatic pollution, Pakistan Journal of Zoology, 40, 2, 123-134.

3. Ali S. S., 1989 - Morphological and biochemical hazards caused by some organochlorinated insecticides onblood and liver of rat, PhD Thesis, Department of Zoology, University of the Punjab, Lahore.

4. Ayoade A. A., Sowunmi A. A. and Nwachukwu H. I., 2004 - Gill asymmetry in Labeo ogunensis from Ogun River, Southwest Nigeria, Revista de Biologia Tropical, 52, 1, 171-175.

5. Chapman D., 1996 - Water quality assessment - A guide to use of biota, sediments and water environmental monitoring, 2nd edition EPFN Spon, London, 626.

6. DWAF, 2001 - Quality of domestic water supplies. www.dwaf.gov.za

7. Hamilton H. E., Morgan D. P. and Simmons A., 1978 - A pesticide (Dieldrin) induced immunohaemolytic anemia, Environmental Research, 17, 155-164.

8. Hrubec T. C., Cardinale J. and Smith S. A., 2000 - Hematology and plasma chemistry reference intervals for cultured tilapia (Oreochromis hybrid), Veterinary Clinical Hematology, 29, 7-12.

9. Jain N. C., 1986 - Schalm’s Veterinary Haematology, 4th edition, Lea and Febiger Philadephia, 1221.

10. Klein L., 1962 - River Pollution II. Causes and Effects, Butterworth and Co. (Publishers) Ltd., London.

11. Koning N. and Roos J. C., 1999 - The continued influence of organic pollution on water quality of the turbid Modder River, Water South Africa, 25, 3, 285-292.

12. Mandal A., Chakraborty S. and Lahiri P., 1986 - Hematological changes produced by lindane (gamma-HCH) in six species of birds, Toxicology, 40, 103-111.

13. Meybeck M. and Helmer R., 1989 - The quality of rivers: from pristine stage to global pollution, Palaeogeography, Palaeoclimatology, Palaeo-ecology (Global Planet Change Section), 75, 283-309. 
14. Mitruka B. M. and Rawnsley H. M., 1977 - Clinical biochemical and haematological reference values in normal experimental animals, MASSON Publishing Inc., USA.

15. Mohammed F. A. S., 2009 - Histopathological studies on Tilapia zilli and Solea vulgaris from lake Quran, Egypt, World Journal of Marine Fish Science, 1, 29-39.

16. Okayi R. G., Daku V. and Mbata F. U., 2013 - Some Aquatic Macrophytes and Water Quality Parameters of river Guma, Benue, Nigeria, Nigerian Journal of Fisheries and Aquaculture, 1, $1,25-30$.

17. O’Neal C. C. and Weirich C. R., 2001 - Effects of low level salinity on production and haematological parameters of channel catfish, Ictalurus punctatus reared in multi crop ponds, Book of abstract, Aquaculture 2001, Triennal Conference of World Aquaculture Society, January, 21-25, 2001, Florida, 484.

18. Pandey K. and Skukla J. P., 2005 - Fish and Fisheries, Rastogi Publications, Meerut, India, 504.

19. Rajgopal T., Thangamani A., Sevarkodiyone S. P., Sekar M. and Archunan G., $2010-$ Zooplankton diversity and physicochemical conditions in three perennial ponds of Virudhunagar district, Tamilnadu, Journal of Environmental Biology, 31, 265-272.

20. Sanap R. R., Mohite A. K., Pingle S. D. and Gunale V. R., 2006 - Evaluation of water qualities of Godawari River with reference to physicochemical parameters, dist. Nasik (M. S.), India, Pollution Research, 25, 4, 775-778.

21. Schalm O. W., 1965 - Interesting features in canine leukocytes, California Veterinarian Journal, 19, 25-27.

22. Shinde S. E., Pathan T. S., Raul K. S. and Sonawane D. L., 2011 - Studies on the physicochemical parameters and correlation coefficient of Harsool-Savangi Dam District Aurangabad, India, Middle-East Journal of Science Research, 3, 8, 544-554.

23. Swingle H. S., 1967 - Method of analysis of waters, organic matter and pond bottom soils used in fisheries research Auburn University, Alabama Research and Development Series, 22, 30.

24. Yakub A. S. and Ugwumba A. A. A., 2009 - Study on the macroinvertebrates fauna of lower Ogun River at Ishasi, Ogun state South West Nigeria, The Zoologist, 7, 65-74.

25. Wetzel R. G., 1975 - Limnology, W. B. Saundrs Co., Philadelphia, 980.

26. WHO, 1994 - Water quality assessments: a guide to the use of biota, sediments and water in environmental monitoring, 2nd edition, Spon, 651.

27. WHO, 2004 - Drinking Water Guidelines available at http://103.whosea.org.tehifor/water.litm/ 130. 